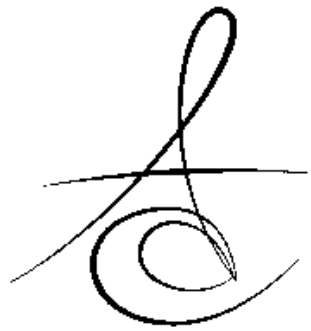

\title{
REKÜRRENT AFTÖZ STOMATİTİS: ETİYOLOJİ ve GÜNCEL TEDAVİ YAKLAŞIMLARI
}

\section{RECURRENT APHTHOUS STOMATITIS: ETIOLOGY and CURRENT TREATMENT APPROACHES}

\section{Dr. Dt. Sara SAMUR ERGÜVEN*}

\author{
Prof. Dr. Ertan DELİLBAŞI**
}

Makale Kodu/Article code: 2011

Makale Gönderilme tarihi: 15.12.2014

Kabul Tarihi: 19.02 .2015

\section{ÖZET}

Rekürrent aftöz stomatitis ağız mukozasının en yaygın hastalıklarından biri olup, toplumun \%5-25'ini etkilemektedir. Lezyonlar her yaşta kadın ve erkeklerde, tüm coğrafi bölgelerde ve ırklarda meydana gelebilmektedir. Rekürrent aftöz stomatitis eritematöz hale ile çevrelenmiş, nekrotik merkeze sahip, yuvarlak şekilli ülserasyon alanları olarak tanımlanmaktadır. Ülserasyonların ağrılı yapısı nedeniyle günümüz tedavi yaklaşımları ağrının giderilmesi ve fonksiyonel bozukluğun planlanmasına yöneliktir.

Birçok çalışmada rekürrent aftöz stomatitis patogenezinde; genetik, immünolojik, mikrobiyal faktörlerin, lokal ve sistemik durumun rolü olabileceği ifade edilmiştir. Bununla birlikte ülserasyonların etiyolojisi, patogenezi ve küratif tedavi yaklaşımları hala büyük ölçüde belirsizdir.

$\mathrm{Bu}$ derlemenin amacı klinisyenleri güncel literatür ışığında rekürrent aftöz stomatitis etiyolojisi, patogenesizi ve tedavi yaklaşımları konusunda bilgilendirmektir.

Anahtar kelimeler: Ağız hastalıkları; Etiyoloji; Stomatit, aftöz; Tedavi

\section{ABSTRACT}

Recurrent aphthous stomatitis is one of the most common oral mucosal disease that affects $5-25 \%$ of the general population. Lesions occur in women and men of all ages, geographic regions and races. Recurrent aphthous stomatitis characterized by a round shape ulceration area with necrotic center and surrounded by an eryhematous halo. Owing to painful nature of the ulcerations, the goal of current treatment approaches includes releaving of pain and management of functional impairment.

Several studies releaved that genetic, immunological, microbial factors, local and systemic conditions may play a role in pathogenesis of recurrent aphthous stomatitis. However; etiology, pathogenesis and curative treatment of this ulcerations have largely remain unknown.

The aim of this review is to inform the clinicians about etiology, pathogenesis and treatment approaches of recurrent aphthous stomatitis in the light of the current literature.

Key words: Etiology; Mouth diseases; Stomatitis, aphthous; Treatment

\section{GİRIŞ}

Aftlar insanoğluna tarih boyunca rahatsızlık veren bir sağlık sorunu olmuş, ilk defa Hipokrat (M.Ö 460-370) tarafından ağız bölgesindeki rahatsızlıkları tanımlamak amacıyla 'aphthai' teriminden yararlanılmıştır. ${ }^{1}$ Aftöz stomatitisler için ilk geçerli klinik tanımlama ise, 1888 yılında Mikulicz ve Kummel tarafından gerçekleştirilmiştir. $^{2}$

Rekürrent aftöz stomatitis (RAS) ağız mukozasının tekrarlayıcı yapıda, yuvarlak veya ovoid şekilli, belirgin sınırlı, sarı-gri tabanlı, eritematöz hale ile çevrelenmiş, çoğunlukla ilk kez çocukluk veya ergenlik döneminde ortaya çıkan ülserleri olarak tanımlanmaktadır. ${ }^{3}$ Tüm dünyada en sık izlenen ağız mukozası hastalıklarından biri olup, genel nüfusun \%5-25'ini etkilediği düşünülmektedir. ${ }^{3-6}$ RAS prevelansını belirlemeye yönelik, 21 farklı ülkeden 10.000 'den fazla genç yetişkin üzerinde gerçekleştirilen kapsamlı çalışmada, erkeklerin \%38,7'si ve kadınların \%49,7'sinin geçmişte iki ya da daha fazla kez, katılımcların \%25'inin ise geçmiş yıl içerisinde en az bir kez RAS lezyonu deneyimledikleri bildirilmiştir. ${ }^{7}$ Hindistan'da yapılan bir 
çalışmada ağız hastalıkları ve radyoloji kliniğine başvuran hastaların \%21,7'sinde RAS mevcudiyeti bildirilmiş olup, lezyonların kadınlarda ve yaşamın üçüncü/ dördüncü dekatlarında daha yüksek seviyede saptandığı bildirilmiştir. ${ }^{8}$ Türkiye'de gerçekleştirilen epidemiyolojik çalışmada genel literatür ile uyumlu yönde lezyonların kadınlarda ve her iki cinsiyet için ya- şamın üçüncü dekadında daha sık olarak tespit edildiği ifade edilmiştir. ${ }^{9}$

RAS ağrılı yapısı nedeniyle hastaların beslenme, yutkunma ve konuşma esnasında zorluk yaşamalarına neden olabilmekte; ağız sağlığını olumsuz yönde etkileyerek yaşam kalitesi üzerine olumsuz yönde etki yapmaktadır. ${ }^{10-12}$ RAS'a ilişkili olarak yaşam kalitesindeki düşüş, dünya çapındaki yüksek dağılım ve sıklık oranları; lezyonların etiyolojisi ve etkili tedavisine yönelik araştırmacıların yoğun ilgi duymalarına neden olmaktadır. ${ }^{13}$ Diş hekimleri RAS'lı bireylerde doğru teşhis ve uygun tedavi yaklaşımları ile hastaların şikayetlerinin giderilmesi/azaltılması veya altta yatabilecek sistemik faktörlerin değerlendirilerek gerekli durumlarda hastalara tıbbi danışmanlık yapılması açısından sorumluluk sahibidir.

\section{ETİYOLOJí}

RAS lezyonlarının etiyolojik nedenleri kesin olarak tanımlanamamış olmakla birlikte çeşitli lokal, sistemik, immünolojik, genetik, alerjik, mikrobiyolojik, hormonal ve nutrisyonel faktörlerin nedensel ilişkisi olduğu öngörülmektedir. ${ }^{1-3}$

Genetik faktörlerin RAS etyopatogenezinde önemli rol oynadığı ortaya konulmuştur. ${ }^{14}$ RAS'lı hastaların \%40'ından fazlasında ailesel öykü mevcut olabileceği bildirilmiştir. ${ }^{1,3,15}$ Pozitif aile hikayesinin mevcut olduğu durumlarda lezyonların daha ciddi seviyede ve erken yaşlarda başlamaya eğilimli olabileceği belirtilmiştir. ${ }^{13,16,17}$ Çeşitli çalışmalarda RAS ve HLA gen alt grupları arasında ilişki belirlendiği bildirilmiştir., ${ }^{1,18}$ Ayrıca İnterlökin-10 ve anjiotensin dönüştürücü enzim insersiyon/delesyon gen polimor- fizmi hastalarda RAS için yatkınlık oluşturan faktörler olarak belirlenmiştir. ${ }^{19,20}$

RAS etiyolojisine yönelik en çok kabul edilen hipotez, hastalığın yatkınlık olan bireylerde genetik kaynaklı bir immünolojik alterasyona bağlı oluştuğudur. Yatkınlık olan hastalarda lokal veya sistemik uyaranların, inflamatuar mediatörlerin serbest kalmasına, ağız mukozası hücrelerinin lenfosit, monosit ve nötrofillerin hedefi olarak yıkıma uğramasına ve aftöz ülserlerin gelişimine sebebiyet verdiği düşünülmektedir. ${ }^{21}$ Ülseratif sürecin mukozal keratinositlerin nedeni bilinmeyen antijenik stimulasyonunu takiben, $\mathrm{T}$ lenfositlerin aktivasyonu, tümor nekrotizan faktör alfa (TNF-a) gibi sitokinlerin salınımı ve lökosit kemotaksisini takiben gerçekleştiği gözlenmiştir. ${ }^{21,22}$ RAS'lı hastalarda tükürükteki TNF-a seviyesinin kontrol grubundaki hastalara göre 2-5 kat daha yüksek seviyede saptandığı ve etiyolojide etkisi olabileceği bildirilmiştir. $^{21}$

Behçet hastalığı, akut febril nötrofilik dermatoz (Sweet sendromu), siklik nötropeni, AIDS (Acquired Immune Deficiency Syndrome-Edinilmiş Bağışıklık Eksikliği Sendromu), periyodik ateş/aftöz stomatitis/ farenjit/servikal adenit sendromu (PFAPA), Crohn hastalığı, çölyak hastalığı gibi altta yatan sistemik hastalıklar mevcudiyetinde ağız mukozasında RAS ve benzeri lezyonlar gelişebilmektedir. 1,3,17,22-24

Anksiyete, depresyon ve psikolojik stres ile RAS lezyonlarının varlığı ve semptomların şiddeti arasında anlamlı ilişki saptanmış olan bir çalışmada, akut dönemdeki RAS'lı hastalarda ağrı şiddeti ve durumluk kaygı düzeyi arasında yüksek kolerasyon belirlenmiştir. $^{25}$

Beslenme yetersizliği RAS oluşumunda yatkınlık oluşturan faktörlerden biri olarak tanımlanmaktadır. Sun ve arkadaşları ${ }^{26}$ RAS'lı hastalarda kontrol grubuna göre hemoglobin, demir, B12 vitamini ve folik asit yetersizliklerinin sıklığının daha yüksek oranda izlendiğini bildirmiştir. Bir diğer çalışmada RAS'lı hastalarda kontrol grubuna göre, serum çinko oranlarının belirgin seviyede düşük, çinko eksikliğinin de daha yüksek oranda izlendiği bildirilmiştir. ${ }^{27}$

Kontrolsüz hiperglisemi düzeyine sahip diabetes mellitus olguları ile periodontitis ve klinik ataşman kaybı ilişkisinin tespit edilmesi, araştırmacıları RAS lezyonları ile glikoz metabolizması bozuklukları arasındaki ilişkiyi sorgulamaya yönlendirmiştir. ${ }^{28}$ Takçı ve arkadaşları $^{29}$ RAS'lı hastalarda yükselmiş insulin direnci saptamış olup, klinisyenlere bu hastaların pre-diyabet açısından izlenebileceği önerisini sunmuşlardır.

RAS ve helicobacter pylori (H. Pylori) enfeksiyonu arasındaki ilişkiyi inceleyen bir meta-analiz çalışmasında, H. Pylori enfeksiyonu yükselmiş RAS riski ile ilişkili bulunmuş, yazarlar midedeki H. Pylor/nin ortadan kaldırılmasının oral ülserlerin iyileşmesi, RAS'ın önlenmesi ve semptomların rahatlatılması açısından 
yarar sağlayabileceğini bildirmiştir. ${ }^{30}$

Bagan ve arkadaşları ${ }^{31}$ kandaki oksidadif stres parametrelerini değerlendirdikleri çalışmada, RAS'ı hastalarda oksidadif stres belirlendiğini ve oksidatif stresin RAS etyopatogenezinde rol oynayabileceğini bildirmiştir. Çağlayan ve arkadaşları ${ }^{4}$ ise RAS oluşumunda tükürükdeki oksidatif stres parametrelerinin etiyolojik rol oynamadığını bildirmiştir.

RAS lezyonları ile sigara içme alışkanlığı arasında negatif bir ilişki varlığı bilinmektedir. ${ }^{32} \mathrm{Bu}$ sonuç RAS etiyolojisinde sigara içmenin oral mukoza üzerindeki potansiyel 'koruyucu etkisinin' düşünülmesine yol açmıştır. Sawair ${ }^{33}$ bu 'koruyucu etkinin' doz ve süre bağımlı olduğunu, ağır sigara tiryakilerinde (>20 sigara/gün) veya uzun dönemli bağımlılıklarda ( $>5$ yıl) gözlemlendiğini bildirmiştir. Tüzün ve arkadaşları ${ }^{34}$ sigara içme ile RAS arasında geçmiş literatür bulgularını destekleyecek şekilde negatif epidemiyolojik ilişki tespit etmiştir. Marakoğlu ve arkadaşları ${ }^{35}$ sigarayı bırakan bireylerde RAS oluşum oranının yükseldiğini ve bu tür hastalarda yaygın bir şikayet olarak RAS oluşumunun gelişebileceğini bildirmiştir.

\section{KLİNİK GÖRÜNÜM}

RAS lezyonları minor, major ve herpetiform olmak üzere üç farklı tipte tanımlanmaktadır.,15,32

Minor RAS: Minor RAS \%70-87 izlenme oranıyla RAS lezyonlarının en sık görülen formudur. ${ }^{15,32,36}$ Lezyonlar ağrıı yapıda, 10 mm'den küçük çapta, yuvarlak veya oval şekilli olup, gri-beyaz psödomembrana sahiptir ve ince eritematöz hale ile çevrelenmiştir. ${ }^{15}$ Sıklıkla ağız tabanı, labial ve bukkal mukozalarda izlenirler. Lezyonlar değişen sıklıklarda oluşabilmekte ve ortalama 10-14 günde skar bırakmadan iyileşmektedir. ${ }^{1,24}$

Major RAS: RAS lezyonlarının yaklaşık \%10'luk kısmını oluşturan, $1 \mathrm{~cm}$ 'den büyük, çok ağrıı yapıda lezyonlardır. ${ }^{3}$ Oval şekilli lezyonlar sıklıkla dudak, yumuşak damak ve tonsiller bölgede izlenirler. ${ }^{24}$ Altı hafta veya daha fazla sürede genellikle skar bırakarak iyileşirler. ${ }^{15}$

Herpetiform RAS: RAS lezyonlarının en az karşılaşılan tipi olup, tekrarlayıcı tipte, çok sayıda, küçük ve ağrılı ülserlerle karakterizedir. Her biri 1-3 $\mathrm{mm}$ çapa sahip olabilen ülserlerin sayısı tek seferde 100 'ü bulabilir.1,3,24 Lezyonlar skar bırakmadan genellikle $10-14$ gün içinde iyileşirler. ${ }^{37}$

\section{DİAGNOZ}

Günümüzde RAS diagnozu hasta anamnezi ve klinik bulgular ışığında gerçekleştirilmektedir. ${ }^{1,24}$ Spesifik bir diagnostik test mevcut olmamakla birlikte, altta yatabilecek olan sistemik faktörler (Behçet hastalığı, PFAPA sendromu gibi) ekarte edilmelidir. ${ }^{3}$ Hematolojik durumun değerlendirilmesi açısından tam kan sayımı, demir, B12 vitamini ve folik asit değerlerini içeren laboratuvar testlerinin istenmesi önerilmektedir. $^{3,32}$ RAS lezyonlarında biyopsi sadece diagnozun belirsiz olduğu vakalarda önerilebilmekle birlikte, sonuç spesifik olmayan inflamatuar lezyon olarak izlenmektedir. ${ }^{22}$ Ayırıcı tanıda Herpes simpleks, pemfigus vulgaris, Coxsackievirus lezyonları düşünülebilmekte olup, bu lezyonlar vezikül/bül oluşumunu takiben başlama, sayı ve lokalizasyon özellikleri ile RAS lezyonlarından ayrılabilmektedir. ${ }^{17}$

Baccaglini ve arkadaşları ${ }^{38} 2013$ yılında yayımlanmış çalışmalarında, önceden geçirilmiş lezyonların değerlendirilmesi gibi klinik muayenenin yapılamadığı durumlarda ya da yaşam boyu prevelansın değerlendirilmesine yönelik çalışmalarda RAS diagnozunun doğruluğunun arttırılmasına yönelik geliştirdikleri ve 'anamnestik diagnoz kriteri' adını verdikleri ölçeğin etkinliğini değerlendirmişlerdir. Yazarlar klinik muayene yapılmadan sadece anket ve temsili RAS fotoğraflarının tanınmasını içeren anamnestik diagnoz kriterinin \%99 oranında diagnostik başarı sağladığını bildirmişlerdir. Geliştirilen değerlendirme sisteminin hatsaların daha önce geçirmiş olduğu RAS lezyonlarının belirlenmesinde ve anamnezin doğruluğunun sağlanması açısından yarar sağlayabileceği düşünülmektedir.

\section{TEDAVi்}

Tedavi uygulamalarında hastanın ağrı ve fonksiyon eksikliğine bağlı şikayetlerinin giderilmesi, lezyonların sayı, büyüklük ve görülme sıklığının azaltılması amaçlanmaktadır. ${ }^{37}$ RAS tedavisinde ilk basamak anamnez ve detaylı klinik muayene ile olası yatkınlık oluşturabilecek faktörlerin (stres, yetersiz ağız hijyeni, sistemik hastalıklar, lokal travma, gıda alerjisi vb.) belirlenmesini ve düzenlenmesini hedeflemektedir. Farmakolojik tedavi seçeneği; öncelikle lokal uygulamalar ile başlamalıdır. ${ }^{22}$ Kortikosteroidlerin (triamsinolon asetonid, betametazon dipropiyonat), antienflamatuar ve antimikrobiyal ajanların (benzidamin hidro-

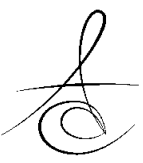


klorür, klorheksidin glukonat, triklosan), lokal anesteziklerin (lidokain jel), antibiyotiklerin (doksisiklin, tetrasiklin) topikal kullanımı tercih edilebilmektedir. ${ }^{3,10,16}$ Lokal tedavide ayrıca bitkisel madde/ karışımlardan, kimyasal koterizasyon özelliği olan maddelerden (gümüş nitrat çubukları), koruyucu bioadhesivlerden ve lazerlerden yararlanılabilmektedir. 5,6,10,36,39

Lokal tedavi seçeneklerinin yetersiz olduğu olgularda sistemik farmakolojik tedavi seçenekleri önerilmektedir. ${ }^{40} \mathrm{Bu}$ amaçla kortikosteroidler (prednizolon), kolşisin, dapson, levamizol, pentoksifilin türü immünomodülatör ilaçlar tercih edilebilmektedir. ${ }^{3,10,16,22}$ Sistemik ilaç tedavisi RAS ataklarının inatçı ve agresif olduğu, lokal tedavi seçeneklerinin yarar sağlamadığı olgularda ilaçların oluşturabileceği yan etkiler göz önünde bulundurularak tercih edilmeli ve konsültasyon yapılarak reçete edilmelidir. Tedavi uygulamaları Tablo 1'de özet olarak izlenmektedir.

Tablo 1. RAS tedavi uygulamaları

\section{Risk faktörlerinin düzenlenmesi}

Ağız hijyeni, stres, beslenme, lokal travma, gıda alerjisi vb.

Lokal farmakolojik tedavi seçenekleri

Topikal kortikosteroidler (triamsinalon asetonid, betametazon valerat, klobetazol propiyonat vb.)

Antimikrobiyaller (triklosan, klorhekzidin glukonat)

Lokal anestezikler (lidokain hidroklorür)

Analjezikler (benzidamin hidroklorür)

Antibiyotikler (doksisiklin, tetrasiklin)

Diğer lokal tedavi seçenekleri (lazerler, koruyucu

bioadhesivler, kimyasal koterizasyon uygulamaları)

Sistemik farmakolojik tedavi seçenekleri*

Sistemik kortikosteroidler (Prednizolon)

Kolşisin

Dapson

Levamizol

Pentoksifilin

*Tıbbi konsültasyon yapılmasını takiben

Scully ve arkadaşları ${ }^{37}$ RAS diagnozu ve tedavi planlamasına yönelik yayımladıkları derlemede tedavi planlamasında kolaylık sağlaması açısından hastaları klinik bulgularına bağlı olarak 3 farklı gruba ayırmayı önermiştir:

Tip A: Ülserlerin yılda birkaç kez, birkaç gün süre ile tolere edilebilecek ağrı seviyelerinde oluştuğu hastalar Tip A olarak sınıflandırılmıştır. Sadece yatkınlık oluşturan etkenlerin tanımlanması ve kontrol edilmesi önerilmiştir. Lokal travmaların engellenmesi, yumuşak diş fırçası kullanımı ve doğru fırçalama tekniğinin öğretilmesi gereklidir. ${ }^{37}$ Ayrıca Tip A hastalarda beslenme alışkanlıklarına yönelik soruların RAS ile beslenme arasındaki olası ilişkinin belirlenmesinde yararlı olabileceği ifade edilmiş; sert ve baharatlı gıdalar, çikolata, asitli içecekler, kabuklu yemişlerden kaçınılması konusunda hastalara bilgi verilmesi önerilmiştir. ${ }^{22}$

Tip B: RAS lezyonlarının aylık epizotlarda, 3-10 gün süren şekilde izlendiği, oluşan ağrının beslenme ve hijyene yönelik kısıtlanma oluşturduğu hastalarda, yatkınlık oluşturan faktörlerin tanımlanması ve topikal tedavi yöntemleri kullanılması önerilmiştir. Ülserlerin ön belirtileri olabilen şişme, karıncalanma hissi deneyimleyen hastaların tanımlanarak; ön belirtilerin oluştuğu aşamada tedavi uygulamasının yapılmasını sağlamanın ülserlerin gelişiminin engellenmesi açısından önem taşıdığı ifade edilmiştir., ${ }^{1,22,37}$

Tip C: Epizotların çok ağrılı olduğu, bir kısmı iyileşirken yeni lezyonların oluştuğu hastalarda önce topikal tedavi denenmesi; yarar sağlamadığı durumlarda intralezyonel ve sistemik tedavi uygulamalarının kullanılması önerilmiştir. ${ }^{1,37}$

Shim ve arkadaşları $^{41}$ sodyum lauryl sülfat içermeyen diş macunlarının RAS hastalarında ağrı skorlarını azaltarak ve iyileşme süresini hızlandırarak hayat kalitesini yükseltebileceğini bildirmiştir.

Albrektson ve arkadaşları ${ }^{10}$ galyum-alüminyumarsenik (GaAIAs) lazer ile uygulanan düşük güç lazer tedavisinin akut minor RAS'larda plasebo grubuna göre ağrı düzeyini ve gıda tüketimi/diş fırçalama işlemleri esnasında oluşan semptomları azalttığını bildirmiştir. Karbondioksit lazer kullanılarak gerçekleştirilmiş bir diğer klinik çalışmada ise lazer tedavisinin minor RAS'larda ağrı rahatlaması sağladığı ve iyileşme sürecini hızlandırdığı ifade edilmiştir. ${ }^{6}$

Jiang ve arkadaşları ${ }^{42}$ tarafından gerçekleştirilen klinik çalışmada minor RAS'larda; diosmectite (doğal alüminyum silikat kaplama) ve bazik fibroblast büyüme faktörü (bFBF) esaslı topikal pat kullanımının ülser ağrılarının giderilmesinde ve mukozal iyileşme sürecinin hızlanmasında etkili olduğu bildirilmiştir. RAS tedavisinde topikal lavanta yağı kullanımının değerlendirildiği bir başka çalışmada, kontrol grubuna kıyasla topikal lavanta yağı kullanılan grupta; ağrı, inflamasyon seviyesi, ülser büyüklüğü ve iyileşme süresi açısından önemli düzeyde azalma sağlandığı ifade edilmiştir. ${ }^{43}$ Minör RAS'ların tedavisinde aloe vera ve reçine bazlı mukoadhesif özellikteki oral jellerin kullanımının değerlendirildiği bir diğer çalışmada, her 
iki jel grubunun kısa dönemli uygulamasının başarılı sonuçlar verdiği bununla birlikte aloe vera jel formunun ülser büyüklüğünün azalması, eritem ve eksudasyon kriterleri; reçine bazlı jelin ise ağrı düzeyinin azalması kriterleri açısından daha başarılı bulunduğu bildirilmiştir. ${ }^{5}$ Antienflamatuar, antimikrobiyal, antitümoral ve antipiretik özellikleri tanımlanmış berberin bitkisi içeren jelatin kullanımının minor RAS tedavisinde etkinliğinin değerlendirildiği klinik çalışma sonuçları, berberin içeren jelatinin ağrı yoğunluğunun azalmasını ve belirgin yan etkiye neden olmaksızın mukozal iyileşmeyi hızlandırdığını bildirmiştir. ${ }^{36}$ Aftöz stomatitislerde gümüş nitrat çubuk aracılığıla gerçekleştirilen kimyasal koterizasyon uygulaması etkinliğinin; ağrı miktarı, ülserlerin çapındaki değişim, iyileşme süresi ve yan etki kriterleri doğrultusunda kontrol grubu ile karşılaştırılarak değerlendirildiği çalışmada, gümüş nitrat uygulaması ağrının giderilmesi ve iyileşme süresi kriterleri açısından anlamlı seviyede etkili bulunmuştur. ${ }^{39}$

Minor RAS izlenen hasta grubunda gerçekleştirilen randomize kontrollü çalışmada günlük sistemik omega-3 tedavisinin ülserlerin sayısı, süresi ve ağrı seviyesinde önemli düzeyde azalma sağlayabileceği bildirilmiş olup yazarlar sistemik omega-3 kullanımının RAS izlenen hasta grubu için güvenilir, makul ve etkin bir tedavi seçeneği olduğunu ifade etmişlerdir. ${ }^{13}$ RAS etiyolojisinde olası etkenlerden biri olarak tanımlanan beslenme yetersizliğinin giderilmesine yönelik multivitamin kullanımının değerlendirildiği bir diğer çalışmada ise, plasebo ve multivitamin desteği alan gruplar arasında yeni RAS sayısı ve iyileşme süresi açısından önemli bir fark izlenmediği bildirilmiştir. Yazarlar klinisyenlerin hastaları RAS profilaksisi amacıyla multivitamin desteği kullanımına yönlendirmesini çalışma bulguları ışığında önermemektedir. ${ }^{44}$ Türkiye'de gerçekleştirilen 2013 yılında yayımlanmış bir çalışmada RAS'lı bireylerde B12 vitamini serum seviyesi kontrol grubuna göre istatistiksel olarak anlamlı düzeyde daha düşük seviyede tespit edilmiş, B12 vitamin desteğinin RAS tedavisine eklenebileceği önerilmiştir. ${ }^{45}$ Samet ve arkadaşları $^{11}$ Ortadoğu'da bazı topluluklarda ağız ülserlerinin tedavisi amacıyla kullanılan arı propolisinin RAS'ı bireylerde rekürrens oranını azalttığını ve yaşam kalitesinin yükselmesine katkı sağladığını bildirmiştir. Çalışmada arı propolisi günlük 500 mg dozda kapsül olarak alınmış olup yazarlar; tedaviye yanıt alınamayan RAS olgularında arı propolisin önerilebilecek bir gıda takviyesi olduğunu ifade etmiştir.
Beslenme ve oral bölge hastalıkları ilişkisinde dikkat çeken konulardan biri de gıda alerjileridir. Bazı araştırıcılar gluten, inek sütü, çikolata, peynir, fındık, koruyucu maddeler, azotlu boyalar ve tatlandırıcı ajanlar gibi gıda maddelerine maruziyet ile ülser başlangıcı arasında ilişki bulunduğunu bildirmiştir. ${ }^{15}$ Besu ve arkadaşları ${ }^{46}$ sistemik bir hastalığı bulunmayan RAS'lı hastalarda inek sütünün içerdiği proteinlere karşı artmış humoral bağışıklık yanıtı tespit etmiştir. Bu konuya yönelik gerçekleştirilen bir diğer çalışmada, inek sütünün içerdiği proteinlere karşı artmış humoral bağışıklık yanıt tespit edilmiş RAS'lı hastalarda keçi sütünün daha iyi tolere edildiği ve alternatif protein kaynağı olarak diyete eklenebileceği bildirilmiştir. ${ }^{47}$

\section{SONUÇ}

Günümüzde etiyolojinin kesin olarak tanımlanamamış olmasının yanında kesin küratif tedavi seçeneğinin olmaması hekimler için RAS tedavisini oldukça güçleştirmektedir. Tedavi semptomatik ve her hastaya özgün olarak planlanmalı, lokal faktörlerin düzenlenmesinin takibinde gerekli durumlarda farmakolojik tedavi seçeneği değerlendirilmelidir. Tedavide semptomların giderilmesi, ülser sayı/büyüklüğünün azaltılması ve ülsersiz dönem süresinin uzatılması hedeflenmelidir.

\section{KAYNAKLAR}

1. Chavan M, Jain H, Diwan N, Khedkar S, Shete A, Durkar S. Recurrent aphthous stomatitis: a review. J Oral Pathol Med. 2012;41: 577-83.

2. Ship JA. Recurrent aphthous stomatitis. An update. Oral Surg Oral Med Oral Pathol Oral Radiol Endod. 1996;81: 141-7.

3. Scully $\mathrm{C}$, Porter $\mathrm{S}$. Oral mucosal disease: recurrent aphthous stomatitis. $\mathrm{Br} \mathrm{J}$ Oral Maxillofac Surg. 2008;46: 198-206.

4. Cağlayan F, Miloglu O, Altun O, Erel O, Yilmaz AB. Oxidative stress and myeloperoxidase levels in saliva of patients with recurrent aphthous stomatitis. Oral Dis. 2008;14: 700-4.

5. Mansour G, Ouda S, Shaker A, Abdallah HM. Clinical efficacy of new aloe vera - and myrrh-based oral mucoadhesive gels in the management of minor recurrent aphthous stomatitis: a randomized, double-blind, vehicle-controlled study. J Oral Pathol Med. 2014;43: 405-9. 
6. Prasad RS, Pai A. Assessment of immediate pain relief with laser treatment in recurrent aphthous stomatitis. Oral Surg Oral Med Oral Pathol Oral Radiol. 2013;116: 189-93.

7. Embil JA, Stephens RG, Manuel FR. Prevalence of recurrent herpes labialis and aphthous ulcers among young adults on six continents. Can Med Assoc J. 1975;113: 627-30.

8. Patil S, Reddy SN, Maheshwari S, Khandelwal S, Shruthi D, Doni B. Prevalence of recurrent aphthous ulceration in the Indian Population. J Clin Exp Dent. 2014;6: e36-40.

9. Miloğlu Ö, Göregen M, Altun O. Doğu Anadolu bölgesindeki rekürrent aftöz ülserasyon sıklığı ve olası risk faktörleri. Atatürk Üniv. Diş Hek. Fak. Derg. 2007;17: 1-5.

10. Albrektson M, Hedström L, Bergh H. Recurrent aphthous stomatitis and pain management with low-level laser therapy: a randomized controlled trial. Oral Surg Oral Med Oral Pathol Oral Radiol. 2014;117: 590-4.

11. Samet N, Laurent C, Susarla SM, SametRubinsteen $\mathrm{N}$. The effect of bee propolis on recurrent aphthous stomatitis: a pilot study. Clin Oral Investig. 2007;11: 143-7.

12. Al-Omiri MK, Karasneh J, Alhijawi MM, Zwiri AM, Scully C, Lynch E. Recurrent aphthous stomatitis (RAS): a preliminary within-subject study of quality of life, oral health impacts and personality profiles. J Oral Pathol Med. 2015;44: 278-83.

13. El Khouli AM, El-Gendy EA. Efficacy of omega-3 in treatment of recurrent aphthous stomatitis and improvement of quality of life: a randomized, double-blind, placebo-controlled study. Oral Surg Oral Med Oral Pathol Oral Radiol. 2014;117: 191-6.

14. Slebioda Z, Szponar E, Kowalska A. Recurrent aphthous stomatitis: genetic aspects of etiology. Postepy Dermatol Alergol. 2013;30: 96-102.

15. Natah SS, Konttinen YT, Enattah NS, Ashammakhi $\mathrm{N}$, Sharkey KA, Häyrinen-Immonen R. Recurrent aphthous ulcers today: a review of the growing knowledge. Int J Oral Maxillofac Surg. 2004;33: 221-34.

16.Wardhana, Datau EA. Recurrent aphthous stomatitis caused by food allergy. Acta Med Indones. 2010;42: 236-40.

17. Çağlayan F, Yılmaz AB. Rekürrent aftöz stomatitis. Atatürk Üniv Diş Hek Fak Derg 2009;19: 47-54.
18. Shohat-Zabarski $R$, Kalderon $S$, Klein $T$, Weinberger A. Close association of HLA-B51 in persons with recurrent aphthous stomatitis. Oral Surg Oral Med Oral Pathol. 1992;74: 455-8.

19. Najafi S, Firooze Moqadam I, Mohammadzadeh M, Bidoki AZ, Yousefi $H$, Farhadi $E$, Tonekaboni $A$, Meighani G, Amirzargar AA, Rezaei N. Interleukin10 gene polymorphisms in recurrent aphthous stomatitis. Immunol Invest. 2014;43: 405-9.

20. Karakus N, Yigit S, Kalkan G, Sezer S. High association of angiotensin-converting enzyme (ACE) gene insertion/deletion (I/D) polymorphism with recurrent aphthous stomatitis. Arch Dermatol Res. 2013;305: 513-7.

21. Eguia-del Valle A, Martinez-Conde-Llamosas $R$, López-Vicente J, Uribarri-Etxebarria A, AguirreUrizar JM. Salivary levels of Tumour Necrosis Factor-alpha in patients with recurrent aphthous stomatitis. Med Oral Patol Oral Cir Bucal. 2011;16: e33-6.

22.Belenguer-Guallar I, Jiménez-Soriano Y, ClaramuntLozano A. Treatment of recurrent aphthous stomatitis. A literature review. J Clin Exp Dent. 2014;6: e168-74.

23. Ferraz EG, Campos Ede J, Sarmento VA, Silva LR. The oral manifestations of celiac disease: information for the pediatric dentist. Pediatr Dent. 2012;34: 485-8.

24. Porter SR, Scully C, Pedersen A. Recurrent aphthous stomatitis. Crit Rev Oral Biol Med. 1998;9: 306-21.

25. Gavic L, Cigic L, Biocina Lukenda D, Gruden V, Gruden Pokupec JS. The role of anxiety, depression, and psychological stress on the clinical status of recurrent aphthous stomatitis and oral lichen planus. J Oral Pathol Med. 2014;43: 410-7.

26. Sun A, Chen HM, Cheng SJ, Wang YP, Chang JY, Wu YC, Chiang CP. Significant association of deficiencies of hemoglobin, iron, vitamin B12, and folic acid and high homocysteine level with recurrent aphthous stomatitis. J Oral Pathol Med. 2015;44: 300-5.

27. Ozler GS. Zinc deficiency in patients with recurrent aphthous stomatitis: a pilot study. J Laryngol Otol. 2014;128: 531-3.

28.Cakir E. Is there any relationship between recurrent oral aphthous stomatitis and prediabetes? Med Hypotheses. 2013;81: 512-3. 
29. Takci Z, Karadag AS, Ertugrul DT, Bilgili SG. Elevated insulin resistance in patients with recurrent aphthous stomatitis. Clin Oral Investig. 2015;19: 1193-7.

30. Li L, Gu H, Zhang G. Association between recurrent aphthous stomatitis and Helicobacter pylori infection: a meta-analysis. Clin Oral Investig. 2014;18: 1553-60.

31. Bagan J, Saez G, Tormos C, Gavalda C, Sanchis JM, Bagan L, Scully C. Oxidative stress and recurrent aphthous stomatitis. Clin Oral Investig. 2014;18: 1919-23.

32. Woo SB, Sonis ST. Recurrent aphthous ulcers: a review of diagnosis and treatment. J Am Dent Assoc. 1996;127: 1202-13.

33. Sawair FA. Does smoking really protect from recurrent aphthous stomatitis? Ther Clin Risk Manag. 2010;6: 573-7.

34. Tüzün $B$, Wolf $R$, Tüzün $Y$, Serdaroğlu $S$. Recurrent aphthous stomatitis and smoking. Int J Dermatol. 2000;39: 358-60.

35. Marakoğlu K, Sezer RE, Toker HC, Marakoğlu I. The recurrent aphthous stomatitis frequency in the smoking cessation people. Clin Oral Investig. 2007;11: 149-53.

36. Jiang XW, Zhang Y, Zhu YL, Zhang H, Lu K, Li FF, Peng HY. Effects of berberine gelatin on recurrent aphthous stomatitis: a randomized, placebocontrolled, double-blind trial in a Chinese cohort. Oral Surg Oral Med Oral Pathol Oral Radiol. 2013;115: 212-7.

37. Scully C, Gorsky M, Lozada-Nur F. The diagnosis and management of recurrent aphthous stomatitis: a consensus approach. J Am Dent Assoc. 2003;134: 200-7.

38. Baccaglini L, Theriaque DW, Shuster JJ, Serrano G, Lalla RV. Validation of anamnestic diagnostic criteria for recurrent aphthous stomatitis. J Oral Pathol Med. 2013;42: 290-4.

39. Soylu Özler G. Silver nitrate cauterization: a treatment option for aphthous stomatitis. J Craniomaxillofac Surg. 2014;42: e281-3.

40. Brocklehurst $P$, Tickle $M$, Glenny $A M$, Lewis $M A$, Pemberton MN, Taylor J, Walsh T, Riley P, Yates JM. Systemic interventions for recurrent aphthous stomatitis (mouth ulcers). Cochrane Database Syst Rev. 2012;9: CD005411.
41. Shim YJ, Choi JH, Ahn HJ, Kwon JS. Effect of sodium lauryl sulfate on recurrent aphthous stomatitis: a randomized controlled clinical trial. Oral Dis. 2012;18: 655-60.

42. Jiang $X W$, Zhang $Y$, Zhang $H$, Lu K, Yang SK, Sun $\mathrm{GL}$. Double-blind, randomized, controlled clinical trial of the effects of diosmectite and basic fibroblast growth factor paste on the treatment of minor recurrent aphthous stomatitis. Oral Surg Oral Med Oral Pathol Oral Radiol. 2013;116: 570-5.

43. Altaei DT. Topical lavender oil for the treatment of recurrent aphthous ulceration. Am J Dent. 2012;25: 39-43.

44. Lalla RV, Choquette LE, Feinn RS, Zawistowski H, Latortue MC, Kelly ET, Baccaglini L. Multivitamin therapy for recurrent aphthous stomatitis: a randomized, double-masked, placebo-controlled trial. J Am Dent Assoc. 2012;143: 370-6.

45. Aynali G, Ozkan M, Aynali A, Ceyhan B, Armağan $H$, Yarıktaş $M$, Doğan $M$. The evaluation of serum vitamin B12, folic acid and hemoglobin levels in patients with recurrent minor aphthous stomatitis. Kulak Burun Bogaz Ihtis Derg. 2013;23: 148-52.

46. Besu I, Jankovic L, Magdu IU, Konic-Ristic A, Raskovic S, Juranic Z. Humoral immunity to cow's milk proteins and gliadin within the etiology of recurrent aphthous ulcers? Oral Dis. 2009;15: 5604.

47. Besu I, Jankovic L, Konic-Ristic A, Damjanovic A, Besu V, Juranic Z. Good tolerance to goat's milk in patients with recurrent aphthous ulcers with increased immunoreactivity to cow's milk proteins. J Oral Pathol Med. 2013;42: 523-7.
Yazışma Adresi
Dr. Dt. Sara SAMUR ERGÜVEN
T.C. Sağılk Bakanlığı
75.Yıl Ağız ve Diş Sağlığı Hastanesi
Ulucanlar Caddesi, Altındağ/Ankara
Tel: 03125959700
E-mail: sara_samur@hotmail.com 